\title{
sciendo \\ Problems of Quality Assurance and Selection of Control Criteria in Laser Cutting Operations of Wood and Wood-Like Materials
}

doi:10.2478/mape-2021-0013

Date of submission to the Editor: 04/2021

Date of acceptance by the Editor: 06/2021

MAPE 2021, volume 4, issue 1, pp. 142-152

\author{
Aleksandra Sobolewska \\ Rzeszow University of Technology, Poland \\ Barbara Ciecińska \\ ORCID ID: 0000-0001-7966-0420 \\ Rzeszow University of Technology, Poland
}

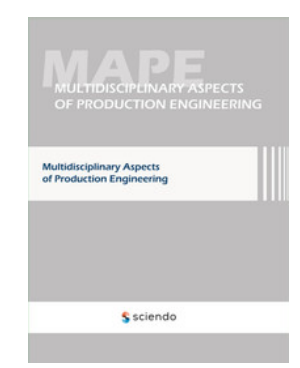

\section{INTRODUCTION}

The concept of quality has evolved over the years. Plato's statement, which thus described the degree of perfection achieved in relation to perfect ideas, has now been replaced by a reference to goods and services (Hamrol and Mantura, 2006) The term "quality" describes the value or essential characteristics of an object that distinguish it from others (Jakość [on-line]). Similarly, this term is defined by the ISO 9001:2015 standard as "the degree to which a set of inherent properties meets the requirements" (EN-ISO 9001:2015). Over the years, quality has been equated with customer satisfaction, timeliness of orders, etc. (Sałaciński, 2016). Companies undertake various activities to create a sense of trust in a customer that their quality requirements will be met. Unfortunately, production problems can be encountered many times, resulting in a decrease of the quality. The reasons for this may be various, e.g. errors made at the product design stage, errors occurring during production (Bugdol, 2018). In order to maintain a competitive advantage, organizational measures are taken to correct inadequate works, processes, etc. In order to determine whether a product meets the quality requirements, it is necessary to define the criteria for classifying the product as good or defective. This state is checked at the quality control stage by comparing the actual state with the expectations. Then a clear decision is made as to whether the requirements are met, and if they are not, to what extent or in which area. There are many areas in which non-conformities may appear, such as the area of design, production, distribution, etc. However, the production stage is the "execution" stage in which the designer's intentions are fulfilled in the context of the customer's needs (Hamrol, 2017). Therefore, quality control after technological operations should finally dispel doubts about the defectiveness of the product.

Due to the complexity of the control process and its various aspects, its varieties can be distinguished regarding the nature of the control (self-control, specialist and inspection control), time of occurrence (initial, operational, final control), 
type of checked feature (numerical control, alternative control), for the controlled product (non-destructive or destructive control), the scope of control (full, step, random), application (conformity assessment, quality capability assessment, supplier assessment, reporting assessment) (Hamrol, 2017).

In the control processes, various methods and measuring tools are used to compare the obtained values with the established, expected values. They may be organoleptic sensations that need to be assessed using the senses (visual assessment, taste, smell, touch, etc.), but they give a subjective picture of the situation. Another way is to use measuring instruments such as e.g. caliper, micrometer; profilometers, protractors, laboratory devices, microscopes, measuring systems integrated with the machine tool, gauges and others (Hamrol, 2017). Then the obtained result can be compared with the given value. In addition to the above-mentioned methods and measuring tools that allow you to verify the correctness of performance, organizational tools can also be used. This is facilitated by the willingness to implement sets of rules, known as management systems. The quality management system is based on the identification and monitoring of processes and continuous improvement in defected areas (Pacana et al., 2017). For effective quality management, various documents are developed that act as a collection of process knowledge. One of the commonly used documents aimed at systematizing the way of proceeding in a given process is the procedure. The procedure clearly and comprehensively indicates the steps involved in the process (EN-ISO 9001:2015).

The general content on quality and its verification in the introduction relates to real-world processes. Based on the above description, one can get the impression that the matter of stating that the customer's requirement is met, i.e. confirming a certain quality, is simple. However, various difficulties may arise with the unambiguous establishment of the criteria for assessing quality. An example may be the process of laser cutting selected materials, in which the effects of the treatment depended on many factors, which was found in the experiment. Dilemmas emerged as to the selection of optimal laser processing conditions in the context of the expected product quality (Sobolewska, A., 2021).

\section{QUALITY ANALYSIS OF LASER CUTTING OF WOOD AND WOOD-LIKE MATERIALS}

Laser cutting of various materials is quite common nowadays. Laser devices available on the market enable the modernization of the machine park, the use of computer methods of programming and machining control. They often allow to replace conventional machine tools, which for various reasons may be unsatisfactory in terms of efficiency and production efficiency, but also are environmentally burdensome. Replacing the older technology with a new one entails the necessity to determine technological parameters that ensure the possibility of making the product, but also to determine the changed causes of potential non-compliance. The new process performed with the use of new tooling and devices means a new risk of loss of product quality. Therefore, it is 
necessary to establish new criteria for assessing this quality and methods of counteracting defects.

\section{Experimental research}

In experimental studies the mechanism of cutting $\mathrm{CO}_{2}$ laser was examined on the selected materials commonly available on the market (Gaczek, M. [on-line]):

- $4 \mathrm{~mm}$ thick pinewood slat (approximate density $520 \mathrm{~kg} / \mathrm{m}^{3}$ ) with unidirectional fiber pattern

- $4 \mathrm{~mm}$ thick plywood (approximate density $680 \mathrm{~kg} / \mathrm{m}^{3}$ ) - consisting of three layers of thin sheets of hardwood wood glued together; about the crossing fibers of individual layers

- $4 \mathrm{~mm}$ thick HDF laminated board (approximate density of $850 \mathrm{~kg} / \mathrm{m}^{3}$ ) made of wood fibers randomly arranged and derived from deciduous and coniferous trees, binders and a hardener. On one side, the plate was covered with white varnish.

These materials were laser cut in an ATMS PRO1390 plotter with $80 \mathrm{~W}$ power and a wavelength of $\sim 10.64 \mu \mathrm{m}$ and cutting speed of $1-200 \mathrm{~mm} / \mathrm{s}$ (Fig. 1) (Ploter [on-line]). The processing in the plotter was program-controlled using the Thunder Laser software. The processing was performed in the variants presented in Table 1.

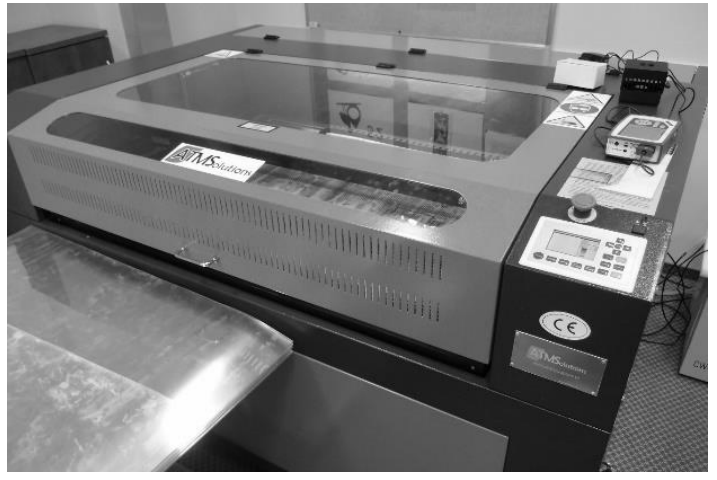

a)

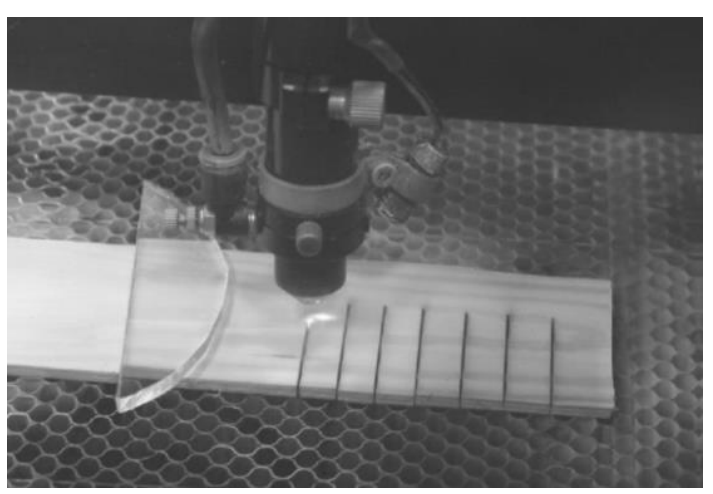

b)

Fig. $1 \mathrm{CO}_{2}$ laser treatment in experimental tests:

a) ATMS PR01390 plotter, b) sample preparation

Table 1 Laser operating parameters - plan of the experiment

\begin{tabular}{|c|ccccccc|}
\hline Laser power, W & \multicolumn{7}{|c|}{ Speed of cutting, $\mathbf{~ m m} / \mathbf{s}$} \\
\hline 80 & 10 & 15 & 20 & 25 & 30 & 35 & 40 \\
\hline 40 & 2 & 4 & 6 & 8 & 10 & 15 & 20 \\
\hline
\end{tabular}

\section{Quality evaluation criteria and results of cutting of selected materials}

A hand microscope was used to assess the quality of the cut site and a feeler gauge to determine the width of the cut to perform a detailed analysis of the laser treatment process and determine the possible defectiveness of the cut materials. 


\section{Wooden plate}

After cutting the plate with a $80 \mathrm{~W}$ laser at a speed in the range of 10 to $40 \mathrm{~mm} / \mathrm{s}$, it was found that the cutting lines from the outside are of similar quality, they are straight with no visible defects, only a small chipping is visible at a speed of 20 $\mathrm{mm} / \mathrm{s}$. On the underside, however, not all cuts are complete: at speeds of 35 and $40 \mathrm{~mm} / \mathrm{s}$, the material was not fully separated. The remaining cuts show visible damage, and at a speed of $10 \mathrm{~mm} / \mathrm{s}$, the material is burnt. An additional problem is the color change, which may be considered as a local defect.

After cutting the plate with a $40 \mathrm{~W}$ laser at a speed in the range of 2 to $20 \mathrm{~mm} / \mathrm{s}$, it was found that the material was separated in all tested variants, the edges were parallel, but local material losses were noticeable. Only after processing at a speed of $2 \mathrm{~mm} / \mathrm{s}$, significant overburning was observed. Changes in the color of the material are noticeable on both surfaces.

In both laser power variants, the slots narrow towards the inside of the material. The appearance of the wooden board after laser cutting tests is shown in Fig. 2.
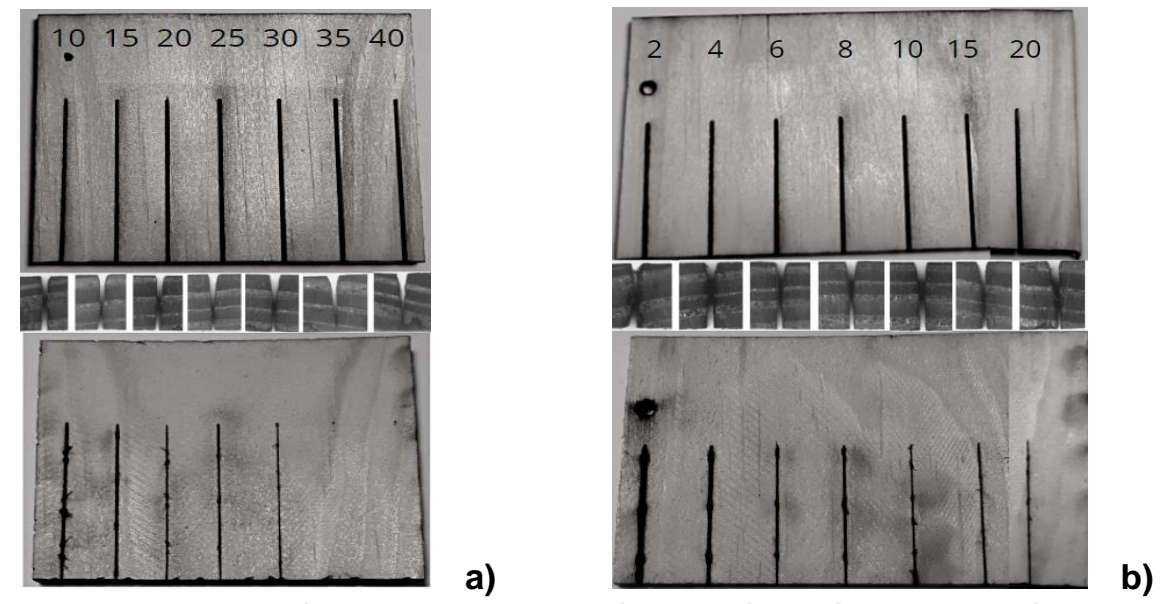

a)

Fig. 2 The appearance of a wooden board after cutting with a laser with a power of: a) $80 \mathrm{~W}$, b) $40 \mathrm{~W}$ on the outer surface, frontal surface and underside (viewed from above)

\section{Plywood}

After cutting the plywood with a $80 \mathrm{~W}$ laser at a speed ranging from 10 to 40 $\mathrm{mm} / \mathrm{s}$, only three full cuts were obtained (with a speed of 10,15 and $20 \mathrm{~mm} / \mathrm{s}$ ). The edges are smooth and their surfaces are parallel. A slight discoloration is noticeable on the outer surface. On the other hand, the underside of the surface is clearly smoky. The edge of the cut has visible defects, the size of which decreases with increasing cutting speed.

After cutting the plywood with a $40 \mathrm{~W}$ laser at a speed ranging from 2 to 20 $\mathrm{mm} / \mathrm{s}$, five distinct cuts were obtained. From the outside, all the cuts are visibly burned, although the edges are not voids. From the bottom, two cuts - made at 2 and $4 \mathrm{~mm} / \mathrm{s}$, are burnt and have unsightly nicks, while at 15 and $20 \mathrm{~mm} / \mathrm{s}$ the plywood was not cut.

The appearance of the plywood after laser cutting tests is shown in Fig. 3. 


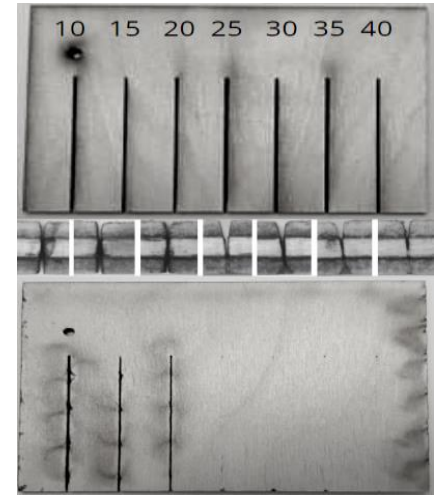

a)

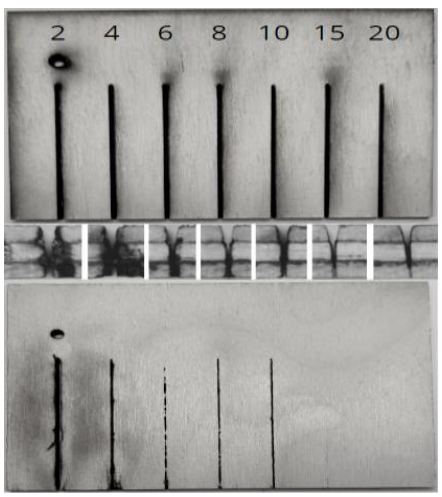

b)

Fig. 3 The appearance of the plywood after cutting with a laser with the power of:

a) $80 \mathrm{~W}$,

b) $40 \mathrm{~W}$ on the outer surface, frontal surface and underside (viewed from above)

\section{HDF board}

As a result of cutting the HDF plate with a $80 \mathrm{~W}$ laser at a speed ranging from 10 to $40 \mathrm{~mm} / \mathrm{s}$, a satisfactory cut was obtained, except for the speeds of 35 and $40 \mathrm{~mm} / \mathrm{s}$. In these cases, there are visible places where the material of the plate has melted and joined again. On the surface covered with white varnish, there are unsightly and irremovable discoloration and burns. On the underside of the slab, there are cavities and areas of changed color.

Cutting the HDF plate with a $40 \mathrm{~W}$ laser at a speed ranging from 2 to $20 \mathrm{~mm} / \mathrm{s}$ made it possible to obtain all the gaps cut completely and the edges parallel. At speeds of 2 and $4 \mathrm{~mm} / \mathrm{s}$, more scorched edges were obtained. Moreover, discoloration of the varnish layer was found in all variants. Numerous nicks with a slight change in color are visible on the underside.

The HDF plate can be placed upside down so that the varnish layer adheres to the table of the laser device. Then, when cutting with the power of $80 \mathrm{~W}$, the varnished layer was more susceptible to discoloration, but no other significant differences in the quality of the material were found. Cutting with a $40 \mathrm{~W}$ laser resulted in very visible, indelible burns and discoloration, although in all variants the board was cut effectively. The width of the slots in both cases did not change. The appearance of the HDF board after laser cutting tests is shown in Fig. 4.

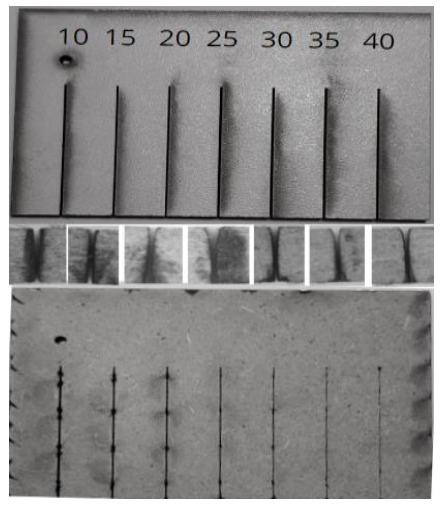

a)

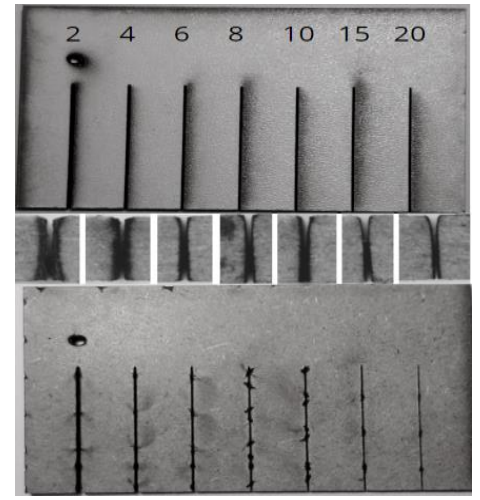

b)

Fig. 4 The appearance of the HDF board after cutting with a laser with the power of:

a) $80 \mathrm{~W}$, b) $40 \mathrm{~W}$ on the outer surface, frontal surface and underside (viewed from above) 
In addition to the visual assessment of the effectiveness and quality of the cut, an analysis of the width of the slots was performed. The results of the measurements made with a feeler gauge are given in Table 2.

Table 2 The width of the gaps after laser cutting of selected materials

\begin{tabular}{|c|c|c|c|c|c|c|c|c|}
\hline Power of laser & \multicolumn{9}{|c|}{$\mathbf{8 0 ~ W}$} \\
\hline Speed of cutting, mm/s & $\mathbf{1 0}$ & $\mathbf{1 5}$ & $\mathbf{2 0}$ & $\mathbf{2 5}$ & $\mathbf{3 0}$ & $\mathbf{3 5}$ & $\mathbf{4 0}$ & Range \\
\hline Wood & 0.27 & 0.25 & 0.22 & 0.22 & 0.20 & - & - & $\mathbf{0 . 2 0 - 0 . 2 7}$ \\
\hline Plywood & 0.35 & 0.27 & 0.22 & - & - & - & - & $\mathbf{0 . 2 2}-\mathbf{0 . 3 5}$ \\
\hline HDF board I & 0.22 & 0.20 & 0.18 & 0.15 & 0.15 & - & - & $\mathbf{0 . 1 5 - 0 . 2 2}$ \\
\hline HDF board II & 0.22 & 0.20 & 0.18 & 0.15 & 0.15 & 0.12 & 0.12 & $\mathbf{0 . 1 2 - 0 . 2 2}$ \\
\hline
\end{tabular}

\begin{tabular}{|c|c|c|c|c|c|c|c|c|}
\hline Power of laser & \multicolumn{9}{|c|}{$\mathbf{4 0 ~ W}$} \\
\hline Speed of cutting, $\mathbf{m m} / \mathbf{s}$ & $\mathbf{2}$ & $\mathbf{4}$ & $\mathbf{6}$ & $\mathbf{8}$ & $\mathbf{1 0}$ & $\mathbf{1 5}$ & $\mathbf{2 0}$ & Range \\
\hline Wood & 0.38 & 0.35 & 0.30 & 0.22 & 0.20 & 0.20 & 0.18 & $\mathbf{0 . 1 8 - 0 . 3 8}$ \\
\hline Plywood & 0.38 & 0.35 & 0.30 & 0.22 & 0.20 & - & - & $\mathbf{0 . 2 0}-\mathbf{0 . 3 8}$ \\
\hline HDF board & 0.45 & 0.30 & 0.25 & 0.22 & 0.20 & 0.18 & 0.15 & $\mathbf{0 . 1 5 - 0 . 4 5}$ \\
\hline HDF board II & 0.45 & 0.30 & 0.25 & 0.22 & 0.20 & 0.18 & 0.15 & $\mathbf{0 . 1 5 - 0 . 4 5}$ \\
\hline
\end{tabular}

where:

HDF board I - top lacquered layer

HDF board II - lacquered layer on the underside

\section{RISK OF DEFECTS DURING CUTTING}

In the case of cut boards, setting the criteria for assessing laser cutting is important because of several choices, e.g.:

- aesthetic appearance of the material separation point (should the outer and bottom surfaces be assessed, or only the outer surface?),

- cutting slot width (minimizing material losses),

- cavities and surface defects, burns near the edges,

- $\quad$ edge parallelism.

The proposed criteria are given in Table 3 in the form of a checklist form. The more "OK" answers, the more features of the product were assessed positively.

Table 3 The form of the laser cutting evaluation criteria checklist

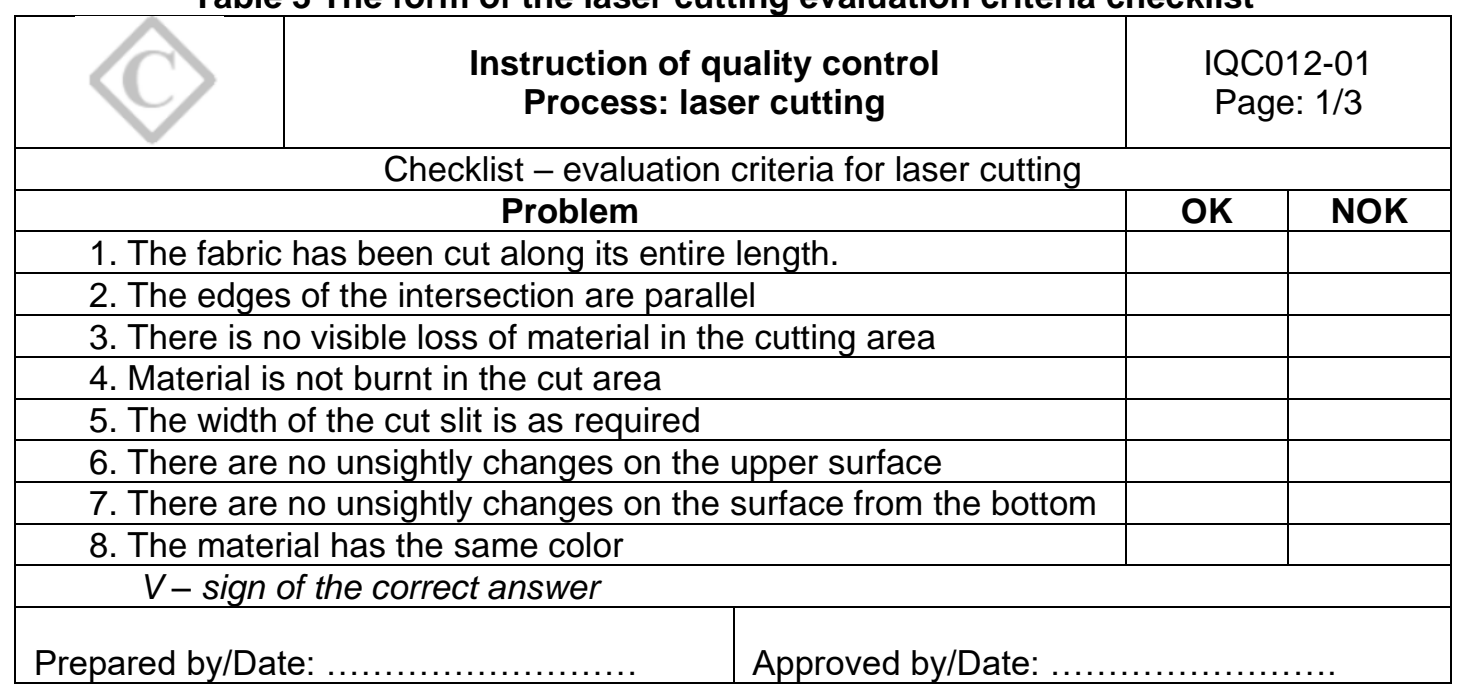


If the material has defects, but they are not significant for the customer and do not change the final value of the product, the question can be omitted from the assessment. However, some features are important and a negative answer, as in the case of question 1, results in the rejection of the product as non-compliant. In a situation where there are no strict assessment conditions imposed, the decision is made by the inspector based on his experience or the product, together with the inspection report, is handed over to the client for a decision.

For the purposes of developing a quality control procedure in the quality management system and response to nonconformities, the organization shall determine the risk of loss of product quality. In addition, action is required to fix, prevent or reduce the undesirable effects of non-compliance (EN-ISO 9001:2015). For this reason, in the process of laser cutting selected materials, a number of potential non-conformities were identified, resulting from improper selection of laser operating parameters. These can be: burning, charring, edge burning, material chipping, chipping, melting of the varnish layer (in case of HDF board). In extreme cases, such as during wood processing, the material may be damaged due to the delamination of the rings (Fig. 5).

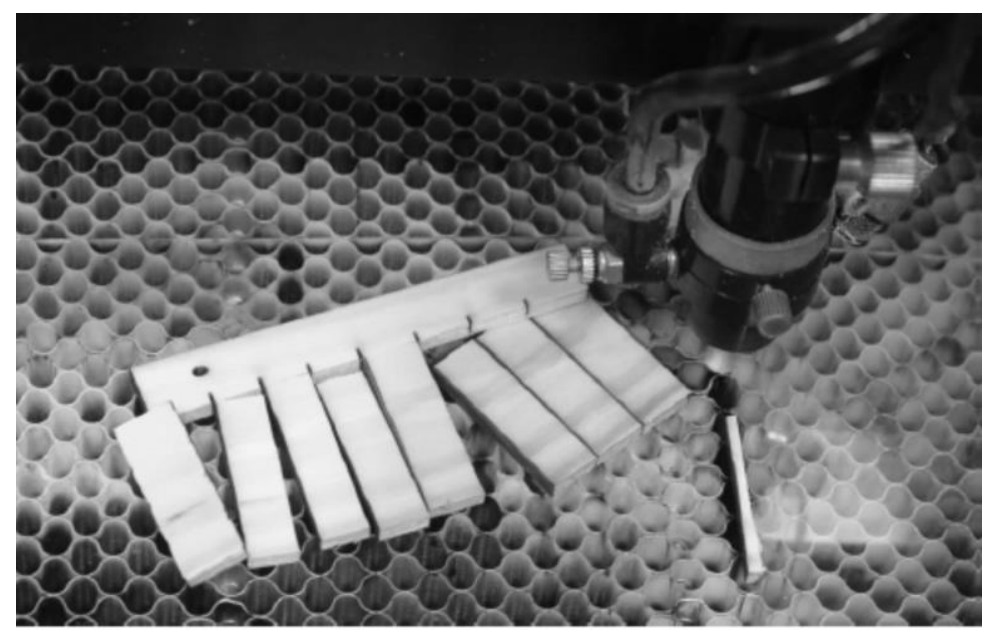

Fig. 5 Example of material failure

The identified problems are shown on the example of the quality management system manual (Table 4). It can be implemented in any company dealing with laser processing. 
Table 4 Example of an instruction with a list of non-conformities

\begin{tabular}{|c|c|c|c|c|}
\hline & \multicolumn{3}{|c|}{$\begin{array}{c}\text { Instruction of quality control } \\
\text { Process: laser cutting }\end{array}$} & $\begin{array}{c}\text { IQC000-01 } \\
\text { Page: } 2 / 3\end{array}$ \\
\hline \multicolumn{3}{|c|}{ List of non-conformities on laser-cut wooden products } \\
\hline 1. Edge scorch & 2. Charring & $\begin{array}{c}\text { 3. Excessive } \\
\text { edge burn }\end{array}$ & 4. Extensive burning \\
& & & \\
\hline
\end{tabular}

\section{RISK OF FAILURE OF THE CUTTING PROCESS}

In the process of cutting materials with a laser, the risk of product defects depends primarily on the selection of laser operating parameters. However, considering the entire quality management context, customer satisfaction may also depend on the quality of the entire service, which is the implementation of the manufacturing process (EN-ISO 9001:2015). Therefore, the timeliness of machining, process efficiency and downtime should also be monitored. Therefore, considering the potential consequences of the failure of the analyzed laser cutting process, a list of hazards for the process was prepared (Table 5). The situations in which the treatment cannot be performed at all were considered critical, while the cases in which the plant employees are able to react to threats and prevent the occurrence of non-compliance were assessed as important. 
Table 5 Risk management - a list of threats to the laser cutting process

\begin{tabular}{|c|c|c|c|c|c|}
\hline \multicolumn{5}{|c|}{$\begin{array}{l}\text { Instruction of quality control } \\
\text { Process: laser cutting }\end{array}$} & $\begin{array}{l}\text { IQC000-01 } \\
\text { Page: } 3 / 3\end{array}$ \\
\hline \multicolumn{6}{|c|}{ Risk management } \\
\hline No. & Threats & Effect & $\begin{array}{l}\text { Responsible } \\
\text { person }\end{array}$ & Importance & Actions \\
\hline 1. & $\begin{array}{l}\text { Technical } \\
\text { limitations } \\
\text { of the plotter }\end{array}$ & $\begin{array}{l}\text { The material } \\
\text { cannot be } \\
\text { processed }\end{array}$ & Technologist & Critical & $\begin{array}{l}\text { Refusal } \\
\text { to perform } \\
\text { machining }\end{array}$ \\
\hline 2. & $\begin{array}{l}\text { Incorrectly } \\
\text { selected } \\
\text { material (grade, } \\
\text { dimensions, } \\
\text { chemical } \\
\text { composition) }\end{array}$ & $\begin{array}{l}\text { Unable } \\
\text { to process } \\
\text { or damage } \\
\text { to the plotter }\end{array}$ & Technologist & Critical & $\begin{array}{l}\text { Refusal } \\
\text { to perform } \\
\text { machining }\end{array}$ \\
\hline 3. & $\begin{array}{l}\text { Material } \\
\text { catching fire }\end{array}$ & $\begin{array}{l}\text { Fire, damage } \\
\text { to the machine }\end{array}$ & Employee & Critical & $\begin{array}{l}\text { Refusal } \\
\text { to perform } \\
\text { machining }\end{array}$ \\
\hline 4. & $\begin{array}{l}\text { Emissions } \\
\text { of toxic gases }\end{array}$ & $\begin{array}{l}\text { Danger of loss } \\
\text { of health }\end{array}$ & Employee & Critical & $\begin{array}{l}\text { Refusal } \\
\text { to perform } \\
\text { machining }\end{array}$ \\
\hline 5. & $\begin{array}{l}\text { Laser focusing } \\
\text { error }\end{array}$ & $\begin{array}{l}\text { Runtime errors } \\
\text { Ineffective } \\
\text { cutting }\end{array}$ & Employee & Essential & $\begin{array}{l}\text { Training } \\
\text { Correct laser } \\
\text { alignment }\end{array}$ \\
\hline 6. & Dirty lens & $\begin{array}{l}\text { Laser beam } \\
\text { focusing errors }\end{array}$ & Service & Essential & $\begin{array}{l}\text { Maintaining } \\
\text { device efficiency }\end{array}$ \\
\hline 7. & $\begin{array}{l}\text { Air nozzle } \\
\text { malfunction }\end{array}$ & $\begin{array}{l}\text { Machining } \\
\text { disruptions }\end{array}$ & Service & Essential & $\begin{array}{l}\text { Training } \\
\text { Maintaining } \\
\text { device efficiency }\end{array}$ \\
\hline 8. & $\begin{array}{l}\text { Plotter software } \\
\text { errors and } \\
\text { security danger }\end{array}$ & $\begin{array}{l}\text { Possible dirt } \\
\text { on the lens }\end{array}$ & Employee & Essential & $\begin{array}{l}\text { The use of anti- } \\
\text { virus software }\end{array}$ \\
\hline 9. & $\begin{array}{l}\text { Error in the } \\
\text { writing of the file }\end{array}$ & $\begin{array}{l}\text { Possible settling } \\
\text { of the molten } \\
\text { material in the } \\
\text { treatment zone }\end{array}$ & Employee & Essential & $\begin{array}{l}\text { Use of legal } \\
\text { software } \\
\text { Carefulness in } \\
\text { saving the copy }\end{array}$ \\
\hline \multicolumn{6}{|c|}{$\begin{array}{l}\mathrm{C}-\text { critical }- \text { lack of cutting possibility } \\
\mathrm{I}-\text { important }- \text { there is possibility of improvement (prevention) }\end{array}$} \\
\hline \multicolumn{3}{|c|}{ Prepared by/Date: } & \multicolumn{3}{|c|}{ Approved by/Date: } \\
\hline
\end{tabular}

\section{DISCUSSION AND CONCLUSION}

The results of laser cutting of selected materials are different, both in terms of the width of the aperture and the visible effects of the laser beam. By appropriately selecting the laser power and the speed of the beam movement, the optimal width of the cut can be selected. Additionally, by visually inspecting the processing site, the product can be classified as good or defective.

In the case of a wooden board, when cutting with a power of $80 \mathrm{~W}$, the narrowest gap can be $0.20 \mathrm{~mm}$ at a speed of $30 \mathrm{~mm} / \mathrm{s}$. Then the selection of these parameters guarantees that the material saving criterion is met. Setting a higher speed does not give a satisfactory separation of the material (it is partially cut). On the other hand, when cutting with a $40 \mathrm{~W}$ laser, greater savings are possible 
(smaller allowance), the gap may have a width of $0.18 \mathrm{~mm}$, but the processing will be slower and should run at a speed of $20 \mathrm{~mm} / \mathrm{s}$.

In the case of plywood, laser processing with a power of $80 \mathrm{~W}$ allows to cut the material with a minimum width of $0.22 \mathrm{~mm}$ at a head speed of $20 \mathrm{~mm} / \mathrm{s}$. $40 \mathrm{~W}$ laser cutting gives a slightly narrower $0.20 \mathrm{~mm}$ gap, but the processing is twice slower, at a speed of $10 \mathrm{~mm} / \mathrm{s}$.

The processing of the HDF board can be done at the highest speed of $30 \mathrm{~mm} / \mathrm{s}$ with an $80 \mathrm{~W}$ laser and $20 \mathrm{~mm} / \mathrm{s}$ with a $40 \mathrm{~W}$ laser, and in both cases the gap has the same $0.15 \mathrm{~mm}$ width.

It can be noticed that for selected materials the same laser operating parameters give different effects (e.g. by comparing the width of the obtained slots or the size of the aperture for one speed), but the common feature is the dilemma which criterion for the selection of technological parameters is more important the minimum allowance or greater process efficiency.

For the customer, however, not production criteria, but e.g. aesthetic criteria, may be important. The appearance of the cut materials is not always satisfactory. In some cases, the edges are not parallel in spite of a small slit. If the customer does not accept the rounded edges of the product, additional finishing treatment should be planned.

Also, slower cutting (e.g. in $40 \mathrm{~W}$ variants) carries the risk of excessive burning, color change, spattering, and the product will be classified as defective. On the other hand, a slight scorch on the edges can be considered as an element contrasting with the color of the material and constitute an aesthetic value.

In the light of obtained results and the made observations, it can be said that in real production situations, before the order is accepted, it will be a good practice to test machining options and analyze potential non-compliance with the subsequent verification of the information obtained with the customer's needs. The proposed solutions in form of data sets for specific materials can be used in practice in the procedures and instructions in the quality management system, as long as it is justified in the company, and such documents will be helpful in ensuring the quality of the machining process.

\section{ACKNOWLEDGEMENT}

Authors would like to thank PhD. Eng. Leszek Pyziak, an employee of the Department of Applied Optics, Faculty of Mathematics and Applied Physics, Rzeszów University of Technology for technical assistance in the implementation of laser treatment.

\section{REFERENCES}

Bugdol, M. (2018) System zarządzania jakością według normy ISO 9001:2015. Gliwice: HELION

Gaczek, M. [on-line]. Podstawowe materiały i wyroby budowlane. Drewno i tworzywa drzewne. Available at:

http://www.ikb.poznan.pl/mariusz.gaczek/pb02_v01.pdf; [Accessed 9 June 2021]. 
Hamrol, A., Mantura, W. (2006) Zarządzanie jakością. Teoria i praktyka. Warszawa: PWN.

Hamrol, A. (2017) Zarządzanie i inżynieria jakości. Warszawa: PWN

Jakość [on-line]. Available at: https://sjp.pwn.pl/sjp/jakosc; [Accessed 9 June 2021].

EN-ISO 9001:2015 Quality Management Systems - Requirements

Pacana, A., Ingaldi, M., Czajkowska, A. (2017) Projektowanie i wdrażanie sformalizowanych systemów zarządzania. Rzeszów: Oficyna Wydawnicza Politechniki Rzeszowskiej

Ploter [on-line] Available at: https://atmsolutions.pl/produkt/527/Ploter_Laserowy_CO2_ATMS_PRO1390 [Accessed 9 June 2021].

Sałaciński, T. (2016) Inżynieria jakości w technikach wytwarzania. Warszawa, Oficyna Wydawnicza Politechniki Warszawskiej

Sobolewska, A. (2021) Projekt procedury kontroli jakości wycinania laserowego wyrobów drewnianych. Diploma thesis, Rzeszów University of Technology.

\begin{abstract}
The paper presents the problem of quality assurance of the laser cutting process of wood and wood-like materials and the selection of optimal processing conditions with respect to the required evaluation criteria. An experiment conducted to identify processing difficulties and potential causes of defects is described. Samples of three materials: pine wood, hardwood plywood and mixed wood HDF with a thickness of $4 \mathrm{~mm}$ were cut with a $\mathrm{CO}_{2}$ laser and visually inspected and the width of the slit was measured. It was found that there was a relationship between the laser operating parameters and the obtained slit width. The higher the cutting speed, the narrower the slit. The obtained numerical results allowed to formulate technological guidelines on the selection of laser parameters depending on the material. In turn, based on the visual inspection, defects depending on the material properties were identified. An example of a non-conformity identification manual was developed, which includes illustrations to enable comparative analysis in production. It was found that in the studied process, different criteria can be adopted to qualify a product as compliant or non-compliant. A dilemma may then arise as to which criterion is more important. Therefore, a quality evaluation criteria verification sheet was proposed. Furthermore, due to the fact that the success of the laser cutting process is also dependent on other factors, a list of risks to the process was made.
\end{abstract}

Keywords: laser cutting, quality criteria, defectiveness, risk 